\title{
Strategy for Strengthening Character Education in Muhammadiyah Boarding School Yogyakarta
}

\author{
Agus Yuliyanto \\ Graduate School \\ Universitas Negeri Yogyakarta \\ Yogyakarta, Indonesia. \\ yuliyanto_agus@yahoo.com
}

\begin{abstract}
Character Education is one of the important elements in the education world especially in facing the era of globalization which has eroded the values of the character of the Indonesian people. Character values that are supposed to be strong to keep all Indonesian people feel unable to deal with the onslaught of the times. Strengthening character education is one of the efforts to improve the condition of the world of education today with the hope that in the future education will be the frontline in improving the condition of the Indonesian people. This study emphasizes how the strategy carried out by the Muhammadiyah Boarding School Yogyakarta in implementing the values of character education to all stakeholders. This study aims to determine the strategy of strengthening character education through the implementation of character values at the Muhammadiyah Boarding School Yogyakarta. This research is a type of descriptive research using a qualitative approach. Data collection uses observation, interview and documentation techniques. The research subjects consisted of Foundation Leaders, Principals, Subject Teachers, and students, The validity of the data was obtained by using the source data triangulation technique, the data analysis used was the inductive data analysis technique from Miles and Huberman with the steps of data collection, data reduction, data presentation and decision making.
\end{abstract}

Keyword-Boarding School, Character Education, Strategy for Strengthening Character Education

\section{INTRODUCTION}

The values of national culture become one of the important elements in fostering the character of citizens such as religious values, independence, friendliness, tolerance, and mutual help, all of which become a characteristic and pride of this nation. However, the preservation and development of cultural values are not optimal, which results in the erosion of the values of the nation's character by the flow of times. The efforts made to strengthen character education are through the implementation of strengthening character education in schools.

The background to these objective conditions raises a collective commitment, not only from the school, but also from the community and the government to act in the form of character building. Good character building and coaching can be done through education. Ki Hajar Dewantara stated that education is an effort to promote the growth of character, mind and body of the child, which should not be separated so that children's life can be achieved [1]. The nature, function, and objectives of national education illustrate that passing education can realize students who are intact both emotionally, spiritually and intellectually.

Schools that are in fact as formal education pathways are still trusted to realize the goals of national education. But over time, according to William Kilpatrick [2], there are many fundamental problems faced by schools, namely other problems that stem from this problem, even academic reform depends on how someone puts the character forward. However, the school that became the hope in planting character values has not been able to run optimally. Schools that become hope in planting values have not been able to optimally do that. Research conducted by Darmiyati Zuchdi, et al [3] found that the institutional context of schools still does not optimally support the implementation of character education, schools have not yet used appropriate value facilities to train decision-making skills, as well as the character education climate in schools in general. still classified as medium, meaning that it is not conducive to character education.

Looking at these portraits optimal character habitation is certainly not only handled by one party, but must be carried out thoroughly by all circles, starting with the family, community, school and government. Previous research focused more on one component, namely school, as a result other supporting component were not touched even though their role was not inferior to the school component. The development of national character is not only the responsibility of the schooling world but also the responsibility of citizenship sites outside of schooling, so that with a combination of school, community and family components, character education is more optimal.

\section{LITERATURE REVIEW}

\section{A. Boarding School}

Boarding school is an English word consisting of two words, boarding and school, boarding means 
riding, and school means school, then absorbed into Indonesian into boarding schools. Khalidah [4] revealed that dormitories are boarding houses for students, employees and so on, while boarding houses are living together in a building or complex. Paul Monroe [5] states that boarding schools as a term are applied to a type of educational institution in the pupils, have been surrendered by their parents or guardians to the care and supervision of the teachers of school, and in which they receive not only instruction, but board and lodging.

Maksudin argues that boarding school is an educational institution for students who not only study, but they live and live together in the institution [6]. Boarding school combines the residence of students in school institutions that are far from their homes and families by being taught religion and learning several subjects. Besides Arsy Karima Zahra [7] revealed that boarding school is a school system with dormitories for students and teachers and school administrators who live in dormitories in the school environment within a certain period usually one semester interspersed with a month's vacation until complete his education. The characteristics of boarding school in accordance with Fernéndez's [8] opinion reveal that "The first characteristic of common to all elite boarding schools is that they identify as independent schools".

Boarding school also educates students to have a tolerant, independent, respectful, non-descendant, indigenous and non-indigenous attitude and to bring nationalism to a sense of freedom and independence in deciding the future destiny of their nation. This was confirmed by Goffman who stated that "With regard to home influence 1 do not believe that sending a boy to boarding school is depriving him of home influence [9]. On the opposite, I think it makes it stronger". In other words, boarding school is in accordance with the education of moral values and teaches children to live more independently.

\section{B. Character Education}

Doni Koesoema states that character education was first coined by German education expert F.W. Foerster [10]. The birth of character education can be said to be an attempt to revive the spiritual ideal of pedagogy that was lost in the flow of positism pioneered by French philosopher and sociologist Auguste Comte. Furthermore, Koesoema sees character education as the overall relational dynamics between individuals with various dimensions, both from within and outside the natural world, so that the person can increasingly appreciate his freedom so that he can be more responsible for his own growth as a person and develop in other people's living environment.

Ratna Megawangi stated that being a person of good character is not due to being born (nature) [11] but depends on how he is nurtured. Fuad Hasan [12] mentions that education leads to the transfer of cultural values and social norms. According to Akhmad Muhaimin [13] character education is a character education plus which involves aspects of knowledge (cognitive), feeling (feeling), and action (action). Without these three aspects, character education will not be effective, so what is needed in character education is not enough with knowledge and then perform actions that are in accordance with knowledge. This is because character education is closely related to values and norms so it must also involve feelings.

This is consistent with Lickona's opinion that character education requires emotional aspects. which by Lickona [14] is called "desiring the good" which means the desire to act virtue. Besides that character education is not only an aspect of "knowing the good", but also "desiring the good" loving the good and "acting the good", so that humans are not like robots that are indoctrinated by certain understandings. Yahya Khan [15] reveals that character education teaches habits of ways of thinking and behaving that help individuals to live and work together as families, state citizens and help them make accountable decisions. Nucci \& Narvaez [16] stated that the aim of character education is to prepare young people to lead a thriving life. This is intended to maximize the potential to be meaningful in fulfilling life. Mohammad Fakry Gaffar [17] stated that character education is a process of transforming the values of life to be developed in one's personality, so that it becomes a life behavior of that person.

\section{Strategy for Strengthening Character Education}

To apply the concept of character value education, several strategies are needed, both directly and indirectly. In character education journals which are disclosed, Maksudin intention Direct strategy starts with the determination of behavior that is considered good as an effort to indoctrinate various teachings. The way is by focusing directly on the teaching through design, illustrating, memorizing and saying. The indirect strategy begins by determining the desired behavior, but by creating a situation that allows good behavior to be practiced. The whole experience is used to develop good behavior.

The implementation strategy of character education applied in schools can be carried out in four ways, namely: (1) Learning (teaching), (2) Modeling, (3) Strengthening, and (4) Habituating. The effectiveness of character education is very much determined by the teaching, modeling, reinforcing and habituating that are carried out simultaneously and continuously. This strategic approach to implementation involves three components that are interrelated with each other, namely schools (campuses), families, and communities. When the components of the school (campus) will fully implement and implement certain values (characters) (priority), then each value that will be invested or practiced must always be delivered by the teacher 
through direct learning (as subjects) or integrating it into each subject.

These priority values must then also be modeled (modeled) regularly and continuously by all residents of the school (campus), since from parking attendants, janitors, security officers, administrative staff, teachers, and school leaders. Furthermore, these values must be strengthened by environmental arrangement and activities in the school (campus) environment. The environmental arrangement here includes placing banners (banners) that lead and provide support for the formation of an atmosphere of school (campus) life with a commendable character.

Strengthening can also be carried out by involving family and community components. The family component includes the development and character building at home. The school (campus) can involve parents to be more concerned about the behavior of their children. While the components of society or community in general are as a vehicle of practice or as a means of control for students' behavior in developing and shaping their character. The school (campus) can communicate and interact with this family and society from time to time periodically.

Habituation can be done in school in various ways and involves many things such as time discipline, dress ethics, social ethics, student treatment of employees, teachers, and leaders, and vice versa. Habits made by leaders, teachers, students, and employees, in the discipline of an educational institution are very strategic steps in forming characters together. The implementation of Character Education Strengthening in various schools is still in the level of knowledge but has not touched the substance of character education. On this basis, in strengthening character education, another strategy must be sought to find out strategies that are suitable and in accordance with the situation and condition of each school

\section{Relevant Research}

Research conducted by Anisa Rizkiana in a journal entitled "The Effect of Boarding School Systems on Character Formation of Students in Darul Arqam Garut, West Java. Based on the results of the research boarding school system is in a good category, with an average number of $75.9 \%$ of these numbers shows good qualifications because it is at intervals of $68 \%$ $83 \%$. Similarly, the students 'characters are in the good category, with an average of $73 \%$, the figure shows good qualifications because they are at intervals of $68 \%-83 \%$ towards the formation of students' character in Ma'had Darul Arqam Garut Region.

The research conducted by Udik Budi Wibowo in a journal entitled "Education in alternative character development strategies", obtained results that character education can be done in various ways such as indoctrination, modeling, and value clarification. In its implementation, character education can also be integrated in a material study of a subject area or given in the form of separate material learning about values, morals or ethics.

Research conducted by Kamin Sumardi in a journal entitled "Portrait of Character Education at the Salafiah Islamic Boarding School", obtained results that character education is not always taught in class, but carried out simultaneously and continuously in and outside the classroom. The success of character education will be influenced by examples and concrete examples in life and in learning activities. Character education cannot be enforced but is carried out as a daily life so that it is inherently attached to every student or student.

The research conducted by Ali Muhtadi in the journal on "Effective Education Implementation Strategy in school", obtained results that to implement character education in schools can be done in four ways, namely, 1) integrating ethics learning material into all subjects relevant schools, 2) implementing manners in everyday life for school residents through example, 3) developing social activity programs, 4) strengthening parental participation and cooperation of all school residents.

The research conducted by Didik Suhardi in a journal on "The Role of Pesantren Based Junior High Schools as an Effort to Plant Character Education for National Generation", obtained results that pesantrenbased schools have a significant role in efforts to shape the nation's character. Islamic boarding school education can form students who are religious, akhlakul hasanah, disciplined, simple, respect for older people, and understand the philosophical life.

\section{RESEARCH METHODS}

The type of research used in this study is descriptive with a qualitative approach. As stated by Creswell that Qualitative research is a process of understanding based on the methodological tradition of inquiry that explores a social or human problem [18]. The researcher builds a complex, holistic picture, analyzing words, reports detailed views of informants, and conducts the study in a natural setting. This research entitled "Character Education Strengthening Strategy in Muhammadiyah Boarding School Yogyakarta ", uses a qualitative research approach where researchers first determine the focus of the research and collect data at the beginning of the research until the end of the research, then the data is described in depth without using numbers or statistical calculations and data are analyzed inductively based on facts found in the field.

This research will be carried out at Muhammadiyah Boarding School Yogyakarta. The reason he chose the research place was because it was a pioneer boarding school based on Muhammadiyah with the rapid development of the number of students 
and had a very qualified character development concept. At the Muhammadiyah Boarding School Yogyakarta, it highly upholds the value of honesty, which is realized by the absence of a system of combating scores in the exam. The study was preceded by observations in May 2018.

Primary data was obtained from informants, namely the chairman of the foundation and the headmaster, teachers in Muhammadiyah Boarding School Yogyakarta. Meanwhile, secondary data comes from existing official documents in the form of notes, pictures, photographs and other materials that can support this research.

The technique used in this study is a triangulation technique by utilizing sources and methods, namely examination techniques and data validity that compares observational data with the results of interviews and by checking the results of findings with data collection techniques. Both triangulation techniques can be explained as follows. The data analysis technique used in this study is an inductive data analysis technique, which is drawing conclusions from specific facts, to then be drawn to the general conclusion (generalization). The steps of data analysis in this study are data reduction, data categorization and unitization, data display, and conclusions

\section{A. Result}

\section{IV.RESULT AND DISCUSSION}

\section{- The process of character habituation through} school culture

The process of further habituation through school culture, in this case the culture of Muhammadiyah Boarding School itself. Muhammadiyah Boarding School has a very important role in the form of personality of students because in this Muhammadiyah Boarding School the characters are instilled. School culture from the vision and mission is the essence of Muhammadiyah Boarding School habits, as well as the habits of school culture embodiment. The culture of Muhammadiyah Boarding School is a school that has a strong foundation in accordance with the Islamic school vision.

Based on habituation events carried out at Muhammadiyah Boarding School Yogyakarta which is a school culture such as a ceremony every Saturday with 3 languages (Indonesian, English and Arabic) as a whole alternating every Saturday, whatever] every morning 10 minutes before enter, prayer before and after the lesson, prayer together both fard prayer and circumcision prayer, Dhuha prayer, fasting every Monday and Thursday, regular routine, giving and answering greetings, filling garbage in the trash, culture, bathing and covering the genitals, coming on time, shaking hands with the teacher if he met, saying frankly and gently, getting used to the location of Inggn and Arabic in everyday conversation (which had been done only to a certain local extent). One school culture that becomes: the characteristic of MBS is every morning the students with teachers shake hands (say greetings), plus smile and greetings.

Muhammadiyah Boarding School has extracurricular that students can attend there. The hope of this extracurricular activity, later the child has a social inclination, morality, wisdom and wisdom in facing and break. The next compulsory extracurricular is the holy site. Tapak Suci is a martial arts extracurricular activity at MBS Yogyakarta. Indonesian Martial Arts College Tapak Suci Putera Muhammadiyah or abbreviated Tapak Suci, is a school, college and martial arts organization which is a member of IPSI (Indonesian Pencak Silat Association). Tapak Suci is included in IPSI Historical Colleges, which are colleges that support the growth and development of IPSI as an organization. Tapak Suci with Islamic principles, sourced from the Qur'an and Sunnah, having a brotherly spirit, are under the auspices of Persyarikatan Muhammadiyah as the $\mathrm{H}$-autonomous organization. Footprint Sum the life experiences they need, through extracurricular activities make a meaningful contribution to students to develop new interests, instill responsibility as citizens, through the experience of character building together, independence, discipline, tolerance and building other positive characters, do not let them find their own space of expressioning the problems they face, even the problems faced by this nation.

The process of habituating the character of citizenship in Ital is related to society. MBS makes the community as a teacher, in order to know the real life. The flagship program for training students is sensitive to the social around them. The flagship activity is charity santri or more commonly known as ABAS. In ABAS santri activities (students) are placed in remote villages that are far from access to technological convenience. There are special environmental criteria that will be occupied by students.

The value of independence is very evident in this HW extracurricular activity as evidenced by the decision of the board of relatives. The board of relatives consists of members of $\mathrm{HW}$ whose are as complete. The relatives of relatives are provided with life skills, scouting, technology and military fields. Regarding character education, the board of relatives is very prepared with the intention to foster and promote independence.

\section{B. Discussion}

Muhammadiyah Boarding School is an educational institution that has an obligation to develop character education. The process of character habituation in the Muhammadiyah 
Boarding School is packaged in a holistic manner, intended to touch the three domains of character education. As stated by Lickona that the importance of three components of good character (components of good character), which consists of moral knowing, moral feeling, and moral action [2]. In the context of the process of habituation of characters at Muhammadiyah Boarding School, the moral knowing stage is conveyed in the class dimension (school or cottage) between students and their teachers.

Moral feeling through direct experience of students in the social and personal context. Furthermore, moral action is realized through concrete actions to live independently, be responsible, discipline, respect between individuals and so forth. Character education should not only teach what is good and what is wrong with children, but character education is more than that character education instills good habits. so, you are used to doing good actions. The size is that students do good deeds according to rules based on the Qur'an and the Sunnah.

\section{- The Process of Habituating Citizenship Characteristics Through School Culture}

Besides that, the next process students are habituation which is carried out in all boarding school environment activities. The habituations carried out at the Muhammadiyah Boarding School Yogyakarta included ceremonies every Saturday with 3 languages (Indonesian, Arabic and English) sequentially / alternately every Saturday, morning apples every day before the bell entered, prayed and dhikr before and after the lesson, Fardh prayers congregate, Dhuha prayers, Monday and Thursday fasting, regular hearings, giving and answering greetings, throwing trash in trash cans, queuing culture, dressing well and covering genitals, coming on time, shaking hands with the teacher if they meet. said being polite and gentle, getting used to speaking English and Arabic in everyday conversation (which had been carried out only to a certain local extent) and dhikr and prayer together before going to sleep.

- Process of character habituation through extracurricular activities

The process of character habituation through extracurricular activities conducted at Muhammadiyah Boarding School there are two extra compulsory activities, namely Tapak Suci and Hizbul Wathan. This Tapak Suci activity has a purpose, namely 1) educating and fostering the dexterity and skills of martial arts as martial arts, sports arts, and preserving the culture of the Indonesian nation, 2) maintaining and developing the proficiency of pencak silat or tapak suci as a noble and moral national culture, which does not deviate from the teachings of Islam and is clean from shirk and misleading, 3) Educating and fostering members to become militant Muhammadiyah cadres.

Hizbul Wathan (HW) is a scout extracurricular in Muhammadiyah schools. The principle used by HW is the same as scouting but combined with Islamic principles. In completing the main task, HW always tries to improve the quality and find practical ways and adjust the conditions in the community in general and members of the scout movement. HW extracurricular activities have character values, 1) foster independence and courage, creativity in each student. 2) train leadership, responsibility and discipline. 3) teach students the meaning of cooperation, 4) foster the care of the santri towards the preservation of the surrounding environment.

\section{- The process of character habituation through community activities}

In habituation activities carried out include social services and distribution of education funds. This activity is carried out to train students to have a good social sensitivity, so that it will inspire people to benefit the surrounding environment. Alms distribution activities are also carried out to bring students closer to the community, as well as the Muhammadiyah Boarding School institution with the community. Sacrificial animal slaughter is also carried out to strengthen the character education of all students and teachers in the school, which begins with providing opportunities for all students and teachers to participate in Qurban activities. ABAS activities have the aim of honing students' sensitivity in life directly into the community. Students are required to live with a poor community, and they must help with all the work of the host. This activity is very good and has the support of all stakeholders at the Muhammadiyah Boarding School.

\section{- Character Cultivation Strategy at Muhammadiyah Boarding School Yogyakarta}

Quigley reveals that the character of citizenship is the attitudes and habits of citizens that support the development of healthy social functions and guarantee the public interest of democratic systems [19]. Creating citizens who have the character of citizenship starts from planting the values of the character of citizenship towards someone starting early. Comprehensive character education at Muhammadiyah Boarding School has captured all character values. The most important and prominent habituation strategy according to Ahmad Izzan [20] is a) giving lessons and advice. b) habituation, c) method of reward and sanctions, and d) the method of exemption from the clerics and their counsel. This is in accordance with the opinion of Narvacz \& Lapsyley which emphasizes 
role habits, modeling, instructions, rewards and punishments in character conditioning strategies [21]. The explanation of the four strategies includes:

\section{a. Give lessons or advice}

Giving his maximal advice is remembering something that softens the heart like reward and punishment so that the one who is remembered gets a lesson. Forming characters in the students will be better if given attention or advice. Because shaping the character of students is accustomed to being good at students and together by establishing good qualities. Basically, the important thing that is accustomed to in the hut environment is the habit of praying fardu, sunnah prayer, fasting and dzikir. This is done so that students become gentler and will affect the better character.

\section{b. Good moral habits}

Habits have an important role in human life. Islam makes habituation as a good moral development strategy, all good things become habits. Because someone is said to be of good character if in real life everyday has three habits, namely thinking of ha] that is good of habits, wanting good things of heart, and doing good things of action.

At Muhammadiyah Boarding School habituation is the key to success in the moral development of santri, especially the character, responsibility, observing each other, democracy, and participating. Habit to build independent character by obeying all rules made in MBS, managing time effectively between school time, dormitory activities, and extracurricular activities, custom washing habits, habituation to solve problems by yourself, familiarizing and tidying up your own room. The Muhammadiyah Student Association (1PM) is one organization that proves the character of the students' independence. The HDI plays a role in regulating the younger siblings in obeying the rules at the Muhammadiyah Boarding School.

The habit of building the character of responsibility is by habituating students to take care of themselves, be responsible for their own behavior and ready to accept sanctions if they commit a violation. Students must be disciplined in all activities ranging from building the morning prayer, fardu prayer to congregation, fasting Monday-Thursday, studying at school, to sleeping again.

The habit of building character respects the dignity of others. In Yogyakarta SBM students consist of various tribes from various regions, some even from abroad, namely Malaysia and Thailand. Through the habit of communicating with system in the dormitory is 24 hours, so they measure each other information starting from the culture and habits in the corridor of the system in MBS. 3S activities (smile, greetings, greetings) are habituations made to develop respect and respect for each other both students and their teachers.

The habit of building characters to participate, MBS is accustomed to developing a sense of belonging to the institution itself. The sense of belonging is demonstrated by the way they must participate in all the programs created by MBS. For example, when a culture of love hygiene is held, students must attend the service every Friday morning at 08.00 a.m. to clean the hut environment. Then participation in carrying out sacrificial activities ranging from skinning to distributing sacrificial animals to the surrounding community.

The habit of supporting the character of democracy through the delivery of aspirations of students represented by the IPM. Every election is held once a year in order to elect the chair of the IPM. Democracy in the classroom is realized through elaborate election with a consensus deliberation system. The learning contract is carried out using an agreement between the teacher and students.

The aim of habituating good character to students in MBS Yogyakarta will prepare them to become good citizens who have social responsibility, respect human rights, obey the law, have national spirit, have democratic character and so on.

\section{c. There are rewards and sanctions (reward and punishment)}

In the process of character education, homogenizing children's behavior and bringing them to a better direction is not easy. For this reason, there needs to be a special strategy that can help the education process towards better change. Among them is to use rewards and punishments in the education process.

From the results interview with several informants, it can be seen that in the Yogyakarta Muhammadiyah Boarding School environment the guidelines for the implementation of sanctions on students who violate the rules of procedure have been determined in a book of santri discipline, so that the implementation is in accordance with the existing rules. According to the santri guidebook the form of sanctions given based on the stages or alternatives of sanctions is that there are 3 types of classifications (1) points $1-75$ are sentenced to seek mufradat, memorize and summarize, development, sweep, mop, ask for advice, clean up the cottage environment, ( 2) points 75-100 are sentenced to lull and read statements, memorize mufradat, clean the toilets, washing using social service and others, (3) points 100-150 are punished 
by calling parents, getting warning letters, suspension, returned to the guardian's parents, wearing a special hijab for female students, bald for santri and others. This is intended to deter students and not repeat their mistakes.

\section{d. Give good examples}

Exemplary habituation is an activity in the form of daily behavior that is not programmed because it is done without limitation of space and time. When looking at the theory and implementation of the habit of characterizing citizenship to students at the Muhammadiyah Boarding School Yogyakarta, Lickona's comprehensive design theory is the basis of his theory [2]. Lickona revealed that there are 9 strategies for demand as teachers, one of which is acting as a caring person, model and mentor.

From the results of the research the environmental teacher of Muhammadiyah Boarding School teachers really played a role as a figure for students to imitate good morals. Teachers in MBS are obliged to discipline, pray together, come and depart on time. not smoking and being living moral for their students. This is in accordance with the opinion of Joy Crosby [22], namely "the importance 'of the teacher as a role model". A teacher must be a good example for his students. Therefore, Najib [23] revealed that the teacher must always be on the right track. on the right path does not deviate and turn, according to the teachings of the holy religion, good customs and government rules. Because students always respect and observe the actions of their teacher.

\section{CONCLUSION}

The process of character building in Muhammadiyah Boarding School Yogyakarta is done holistically through a process of integration in both teaching and learning, school culture, extracurricular activities and community activities. All programs for students, both daily, weekly, monthly and yearly, contain the values of the citizenship characteristics they wish to apply. The strategies used to habituate the character of citizenship are carried out through giving advice, good moral habituation, reward and punishment, and exemplary teachers.

Supporting factors in habituating the character of citizenship consist of internal and external factors. Internal factors in the form of rules of order and school culture, good support and cooperation between all school residents, and support from parents. External factors include support and cooperation between the school and the community. The inhibiting factors are the lack of facilities and infrastructure, the proportion that is not balanced between dormitories and member of students, financing, character of students with different backgrounds.

\section{REFERENCE}

[1] Kementerian Pendidikan Nasional. "Pengembangan Pendidikan Budaya dan Karakter Bangsa”. Jakarta: Kementerian Pendidikan Nasional, 2010.

[2] Lickona, Thomas. "Pendidikan Karakter Panduan Lengkap Mendidik Siswa menjadi Pintar dan Baik”. Bandung: Nusa Media, 2013.

[3] Zuchdi, Darmiyati. "Pemetaan Implementasi Pendidikan Karakter di SD, SMP dan SMA di Kota Yogyakarta". Yogyakarta: Pascasarjana UNY

[4] Khalidah. "Pendidikan Karakter dalam Sistem Boarding School”. Yogyakarta: UIN Sunan Kalijaga, 2013.

[5] Monroe, Paul. "A Clyclopedia of Education". USA: Norwood Press, 1915

[6] Maksudin. "Pendidikan Islam Alternatif: Membangun Karakter melalui Sistem Boarding School". Yogyakarta: UNY Press, 2013

[7] Karima Zahra, Arsy. "Pemilihan Program Belajar yang Baik". Diakses 10 Mei, 2018.

[8] Fernandez, Ruben Gaztambide. "What is an Elite Boarding School". USA: America Educational Research Association, 2009.

[9] Erving, Gofman. "The Characteristic of Total Institution: A Sociological Reader on Complex Organization". New York: Holtrinehart and Winston, 1969.

[10] Koesoema, Doni. "Pendidikan Karakter". Jakarta: Gramedia, 2007.

[11] Megawangi, Ratna. "Pendidikan Karakter Solusi Tepat untuk Membangun Bangsa". Bogor: Indonesia Heritage Foundation, 2004

[12] Majid, Abdul. "Pendidikan Karakter Perspektif Islam". Bandung: Remaja Rosda Karya, 2011

[13] Azzet, Akhmad Muhaimin. "Urgensi Pendidikan Karakater di Indonesia”. Yogyakarta: Ar-Ruzz Media, 2011.

[14] Lickona, Thomas. "Educating for Character". New York: Bantam Books, 1991.

[15] Yahya Khan. "Pendidikan Karakter Berbasis Potensi Diri". Semarang: Pelangi Publishing, 2010.

[16] Nucci, L.P, \& Harvaaez, D. "Handbook of Moral and Character Education". New York: Routledge, 2008.

[17] Fakhry Gaffar, Muhammad. "Pendidikan Karakter Berbasis Islam.”. Yogyakarta: Dalam Seminar Pendidikan Karakter Berbasis Islam, 2010.

[18] Creswell, J. "Research Design Qualitative, Quantitative and Mixed Approaches, Thousand Oak", 2013.

[19] Quigley,C. C.,N Buchanan, Jr. J H., Bahmueller, C F." Civitas : A Framework for Civic Education". Calabasas: Center for Civic Education, 1991

[20] Izzan, Ahmad. "Membangun Guru Berkarakter". Bandung: Humaniora, 2012

[21] Narvaez, D., \& Lapsley, D.K. "The Psychological Foundation of Moral: Character Psychology and Character Education". Notre Dame: University of Notre Dame Press, 2005.

[22] Crosby, Joy."The Good Teacher is More the Lecture: the Twelve Roles of the Teacher". AMEE Education No. 20 Schoottish Counchil for Postgraduate Medical \& Dental Education. Medical Teacher 22(4): page 334-347, 2000.

[23] Najib Sulhan." Pembangunan Karakter pada Anak". Surabaya: Intelektual Club, 2010. 